\title{
Phospholipid fatty acids in soil—drawbacks and future prospects
}

\author{
Rainer Georg Joergensen ${ }^{1}[$
}

Received: 14 June 2021 / Revised: 26 November 2021 / Accepted: 29 November 2021 / Published online: 4 December 2021

(c) The Author(s) 2021

\begin{abstract}
The current opinion and position paper highlights (1) correct assignation of indicator phospholipid fatty acids (PLFA), (2) specificity and recycling of PLFA in microorganisms, and (3) complete extraction and detection of PLFA. The straightchain PLFA 14:0, 15:0, 16:0, and 17:0 occur in all microorganisms, i.e., also in fungi and not only in bacteria. If the phylum Actinobacteria is excluded from the group of Gram-positive bacteria, all remaining bacteria belong to the bacterial phylum Firmicutes, which should be considered. The PLFA 16:105 should be used as an indicator for the biomass of arbuscular mycorrhizal fungi (AMF) as there is no experimental evidence that they occur in marked amounts in Gram-negative bacteria. Fungal PLFA should embrace the AMF-specific 16:1 $\omega 5$. In the presence of plants, ergosterol should be used instead of the PLFA 18:2 $\omega 6,9$ and 18:1 $\omega 9$ as fungal indicators for Mucoromycotina, Ascomycota, and Basidiomycota. The majority of indicator PLFA are not fully specific for a certain microbial group. This problem might be intensified by recycling processes during decomposition to an unknown extent. Soil handling and extraction conditions should be further optimized. The reliability and accuracy of gas chromatographic separation need to be regularly checked against unintentional variations. PLFA analysis will still be of interest over the next decades as an important independent control of DNA-based methods.
\end{abstract}

Keywords Fungi $\cdot$ Bacteria $\cdot$ Actinobacteria $\cdot$ Firmicutes $\cdot$ PLFA assignation

\section{Introduction}

Phospholipid fatty acids (PLFA) are the main components of cell membranes in all organisms other than archaea and do not occur in storage components (Zelles 1999). PLFA are rapidly synthesized during microbial growth and do not accumulate in soil organic matter (Zelles 1999; Zhang et al. 2019). Consequently, the total PLFA concentration is used as an indicator for microbial biomass in soil (Frostegård et al. 1991; Joergensen and Emmerling 2006), largely consisting of viable but non-culturable organisms (Zelles 1999). This contrasts neutral lipid fatty acids (NLFA), which are storage components, especially in fungi, and give interesting information on the nutritional status of fungi (Bååth 2003). Total fatty acid methyl ester (FAME) or ester-linked (EL) total FAME have been repeatedly determined in soil by in situ hydrolysis and methylation reactions of fatty acids, without the PLFA extraction step (Acosta-Martínez et al. 2010; Li

Rainer Georg Joergensen

joerge@uni-kassel.de

1 Soil Biology and Plant Nutrition, University of Kassel, Nordbahnhofstr, 1a, 37213 Witzenhausen, Germany et al. 2020). Total FAME and EL-FAME give similar information on the composition of the main microbial groups to that provided by PLFA (Acosta-Martínez et al. 2010) but create an additional link to the formation of microbial necromass from decaying biomass by different microbial groups (Miltner et al. 2012). This link warrants further elaboration as microbial necromass has been recognized as an important source of soil organic carbon (Liang et al. 2020).

PLFA are not only an indicator for soil microbial biomass, with a variety of indicator PLFA (Table 1) providing information on the composition of large and important main microbial groups (Joergensen and Wichern 2008). Soil bacteria consist of Gram-negative (G-) and Grampositive $(G+)$ bacteria, the latter formed by the two bacterial phyla Firmicutes (with low guanine-cytosine content) and Actinobacteria (with high guanine-cytosine content). Soil fungi largely consist of biotrophic arbuscular mycorrhizal fungi (AMF), and Mucoromycotina, Ascomycota, and Basidiomycota, mainly saprotrophic in arable and grassland soils. PLFA analysis is an important independent control of DNA-based analytical methods and may help to reduce the occurrence of alternative facts created by different methodological approaches in soil 
Table 1 Assignment of PLFA to different main microbial groups

\author{
Bacterial PLFA: Gram-positive (G+)+ Gram-negative (G-) \\ $\mathrm{G}+$ : Firmicutes + Actinobacteria \\ Firmicutes: i14:0, i15:0 ${ }^{\mathrm{a}}$, i16:0 ${ }^{\mathrm{a}}$, i17:0, i18, a15:0, a16:0, a17:0, a18:0, a19:0 \\ Actinobacteria: 10Me16:0, 10Me17:0, 10Me18:0

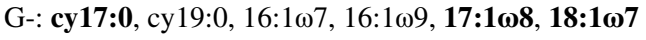 \\ Fungal PLFA: AMF+Zygomycota + Ascomycota and Basidiomycota + unspecific fungal \\ AMF: 16:1 $\omega 5 \mathrm{c}^{\mathrm{b}}$

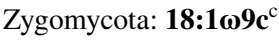 \\ Ascomycota and Basidiomycota: 18:2 $\mathbf{6} 6 \mathbf{c}^{\mathrm{d}}$ \\ Unspecific fungal PLFA: 18:3 $\omega 6,9,12^{\mathrm{d}}$ \\ Unspecific microbial PLFA: 14:0, 15:0, 16:0 ${ }^{\mathrm{d}}$, 17:0, 18:0, 20:0, 20:416,9,12,15 \\ Total microbial PLFA: bacterial + fungal + unspecific microbial \\ Bold: $>1$ mol\% contribution to total PLFA in soil (Murugan et al. 2021) \\ ${ }^{a}$ Also some cultured G- bacteria contained higher concentrations of PLFA i15:0 and i16:0 (Zelles 1997) \\ ${ }^{\mathrm{b}}$ Also some cultured G- bacteria contained minor concentrations of PLFA 16:1 15 (Nichols et al. 1986; \\ Kieft et al. 1997; Zelles 1997) \\ ${ }^{c}$ Also some cultured G- bacteria and plants contained higher concentrations of PLFA 18:1 $\omega 9$ (Zelles 1997)

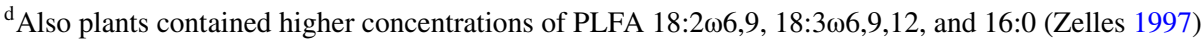

microbiology. In addition, the comparison of membrane components such as PLFA and ergosterol with 16S-rRNA or 18sRNA gene abundance gives information on the cell size of bacteria and fungi in soil and animal feces (Meyer et al. 2021), i.e., oligotrophic or copiotrophic conditions. PLFA-specific analysis of the ${ }^{13} \mathrm{C} /{ }^{12} \mathrm{C}$ ratio makes it possible to measure the incorporation of fresh plant substrate into PLFA (Lønne Enggrob et al. 2020). The ratio of $\mathrm{G}+$ to $\mathrm{G}$ - bacteria is important for estimating the contribution of bacterial necromass to SOC, using amino sugar analysis (Joergensen 2018; Meyer et al. 2021). An additional advantage is that PLFA analysis does not require membrane integrity before extraction, i.e., the soil samples (Wagner et al. 2007) but also extracts (Allison and Miller 2005) can be stored frozen for extended periods. No other method provides information on such a variety of microbial composition characteristics in a single analysis (Willers et al. 2015), especially in combination with stable isotope probing (SIP).

Although Frostegård et al. (2011) gave examples for the misuse of the PLFA approach in soil science, many problems remained unsolved in many manuscripts, using PLFA as a method for investigating the composition of the main microbial groups. This is especially true for the interpretation of PLFA data in many studies (Willers et al. 2015). The objective of the current opinion and position paper is to highlight several persisting problems: (1) correct assignation of indicator PLFA, (2) specificity and recycling of PLFA in microorganisms, and (3) complete extraction and detection of PLFA.

\section{Correct assignation}

In soil biology, the assignation of indicator PLFA to microbial groups is often not congruent with basic microbiological knowledge. This is especially a problem when failing to assign Actinobacterial PLFA to the group of $\mathrm{G}+$ bacterial PLFA and AMF PLFA to the group of fungal PLFA, as well as when assigning unspecific microbial PLFA as bacterial PLFA.

The straight-chain PLFA 14:0, 15:0, 16:0, 17:0, 18:0, and 20:0 were often assigned as bacterial PLFA (e.g., Yang et al. 2017; Wang et al. 2018). However, they occur in all microorganisms, i.e., also in fungi and not only in bacteria as clearly demonstrated by Zelles (1997) based on PLFA analysis of cultured microorganisms. One reason for this perpetual fault might be that PLFA analysis was initially introduced from sediment microbiology (Guckert et al. 1985), where the microbiome seems to consist nearly exclusively of bacteria. However, also the ratios of

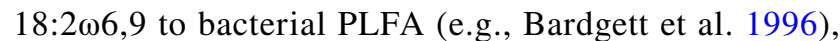
fungal to bacterial gene copies (Jan et al. 2020; Meyer et al. 2021), and fungal to bacterial CFU (Jan et al. 2020) give the wrong impression that fungi also contribute only minor percentages to the soil microbiome. This is unlikely as most of the plant $C$ input consists of cell-wall material such as hemicellulose, cellulose, and lignin, nearly exclusively decomposed by fungi.

The staining method of bacterial cell-walls, developed by the Danish scientist Hans Christian Gram in the 
nineteenth century, remains an important criterion for differentiating bacterial phyla. $\mathrm{G}+$ bacteria consist of the two phyla Firmicutes and Actinobacteria (no longer actinomycetes!). The PLFA 10Me16:0, 10Me17:0, and 10Me18:0 indicate Actinobacteria, but they were often not assigned as $\mathrm{G}+$ bacteria (e.g., Wang et al. 2018), although this is old text-book knowledge. G + bacteria were often regarded as slow growing bacteria (Fanin et al. 2019). However, this is mainly true for Actinobacteria, which are capable of degrading cell wall components, such as chitin and cellulose (Lacombe-Harvey et al. 2018). In contrast, many bacteria of the Firmicutes phylum are the most rapidly growing micoorganisms, e.g., lactobacilli, enterococci, and streptococci. The extraordinarily rapid growth of $\mathrm{G}+$ bacteria in soil has recently been shown by Lønne Enggrob et al. (2020). Consequently, good reasons exist to differentiate Actinobacteria from Firmicutes, but in this case, these bacteria should be denoted as Firmicutes and not as $\mathrm{G}+$ bacteria.

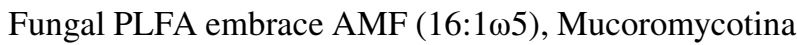
$(18 \omega 1: 9 c, 18.3 \omega 6,9,12)$, Basidiomycota and Ascomycota $(18: 2 \omega 6,9,18.3 \omega 6,9,12)$ in soil. However, AMF-PLFA are often not considered as fungal PLFA (e.g., Yang et al. 2017; Wang et al. 2018; Hansen et al. 2019). One reason might be that the PLFA 16:1 $\omega 5$ was for many years not an accepted AMF-specific indicator due the false belief that there are serious interferences with G- bacteria. However, direct experimental evidence is missing as this PLFA has been found only in minute amounts in G- bacteria (Nichols et al. 1986; Kieft et al. 1997; Zelles 1997). It should be further considered that G- bacteria contribute most likely only $10 \%$ to the total microbial biomass (Joergensen and Wichern 2008; Murugan et al. 2021), i.e., markedly less than AMF (Faust et al. 2017). For this reason, the neutral lipid fatty acid (NLFA) 16:1 15 has sometimes been used as an AMF indicator (Jiang et al. 2020) although NLFA do not solely occur in the biomass of organisms (Zelles 1999). Faust et al.

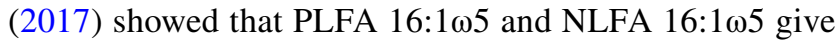
similar information on the presence of AMF in soil and recommended solely using the PLFA as an indicator for AMF biomass. However, it is better to analyze the NLFA 16:1 15 than to simply ignore AMF (e.g., Xu et al. 2021).

\section{Extractability and temporal variation}

PLFA are usually extracted from soil with various modifications of the Bligh and Dyer (1959) procedure, followed by purification with silicic acid chromatography (Frostegård et al. 1991), separation by capillary gas chromatography (GC), and detection using a mass spectrometer (MS) or a flame ionization detector (FID) (Frostegård and Bååth 1996). The content of total PLFA often showed strong temporal variation between different sampling dates (e.g., Hamer et al. 2008; Murugan et al. 2021), which have often been explained as seasonal changes in microbial biomass. These changes were often accompanied by significant changes in the composition of the main microbial groups according to PCA (principal component analysis), although the shifts in the contribution of single PLFA to total PLFA were small (Zelles 1999; Hamer et al. 2008). However, PCA overinterprets small shifts in PLFA composition (Martínez-Abraín 2008), suggesting that more emphasis should be placed on the interrelationships of the different main microbial groups.

In the incubation study of Murugan et al. (2021), the significant variation in total PLFA contents between the sampling days was not accompanied by changes in $\mathrm{CO}_{2}$ evolution and enzyme activities. One reason for the temporal changes in total PLFA contents might be the varying contribution of non-ester-linked PLFA, which may add a highly variable contribution to the true total PLFA content (Zelles 1999). The extent of differences in bonding strength between non-ester-linked and ester-linked PLFA is virtually unknown and might vary between different extraction events of a time series. Also, betaine lipids and other polar lipids seem to contribute a variable percentage to the fraction, which should be purely PLFA (Warren 2019).

Changes in soil moisture affect hydrophobicity (Fu et al. 2021) and, thus, extraction efficiency of PLFA. Zelles (1999) extracted $100 \%$ more total PLFA from a hydrophilic moist soil than from a hydrophobic dry soil. This is certainly an important reason for temporal changes in total PLFA content. However, the available advice to optimize PLFA extraction efficiency by sample pre-treatment, such as moisture adjustment, sieving, and pre-incubation, is still limited. Not only soil properties but also solvent and buffer composition significantly affect quantity and profile of PLFA extracted from soil (Papadopoulou et al. 2011). Other analytical constraints, e.g., aging of the capillary GC columns and small shifts in gas flow conditions, might cause insufficient separation of different PLFA and cochromatographing (Joergensen and Wichern 2008). Such unintentional variation in PLFA extraction conditions could presumably largely explain the changes observed after long-term storage (Wu et al. 2009; Veum et al. 2019). For optimizing the extraction conditions and for controlling GC separation, photometric measurement of total PLFA should be considered (Frostegård et al. 1991). An important independent control for the reliability of extraction and detection procedures might be the comparison of total PLFA and microbial biomass $\mathrm{C}$ measured by fumigation extraction or substrate-induced respiration (Willers et al. 2015). 


\section{Specificity and recycling of PLFA}

One main problem of the PLFA method, which must be accepted to certain extent, is the imperfect specificity of virtually all PLFA for a certain microbial group in soil, in contrast to fungal ergosterol (Joergensen and Wichern 2008) or bacterial muramic acid (Joergensen 2018). This is especially true for the fungal indicator PLFA linoleic

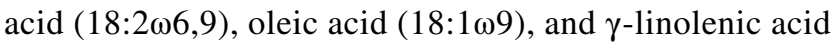
$(18: 3 \omega 6,9,12)$, which sometimes occur in large concentrations in plants, as indicated by their names. However, the removal of plant debris by sieving and tweezers picking reduces these interferences to an acceptable level (Kaiser et al. 2010). In the presence of plant tissue, ergosterol should replace the indicator PLFA 18:2 $\omega 6,9,18: 1 \omega 9$, 18:3 $\omega 6,9,12$ for Mucoromycotina, Ascomycota, and Basidiomycota (Joergensen and Wichern 2008). A close correlation of ergosterol and PLFA 18:2 $\omega 6,9$ has been shown in the absence of living plants (Frostegård and Bååth 1996).

Another inherent problem of the PLFA method is that these membrane components remain in soil after cell death for certain and largely unknown periods (Zelles 1999). This means that the PLFA approach is not suitable for short-term experiments with a rapid sequence of microbial growth and death processes.

Dormant soil microorganisms can recycle their own cell-membrane PLFA, but also that taken up during decomposition of plant material and decaying neighbors (Dippold and Kuzyakov 2016). Such PLFA recycling might further lower the specificity of indicator PLFA in soil but is certainly a highly interesting feature when analyzing the survival mechanisms of microorganisms in soil.

\section{Number of PLFA determined}

The number of PLFA used as a group specific indicator by the simple PLFA extraction procedure proposed by Frostegård and Bååth (1996) varies between 13 and 70 (Zelles 1999). Total PLFA often but not always consisted of the 29 listed in Table 1, dominated by the 16 PLFA shown in bold, which contribute more than $1 \mathrm{~mol} \%$ to total PLFA. The range in detected and evaluated PLFA might affect the total PLFA content to an unknown extent. For this reason, all PLFA used for the calculation of total PLFA should be clearly listed in the Materials and Methods sections, especially as several unspecific microbial PLFA exist (Table 1).

The extended PLFA extraction procedure of Zelles (1999), which can detect up to 400 lipids, results in 21 to $50 \%$ higher total PLFA contents. However, this extended procedure has gained less popularity in the past two decades, despite its ability to identify high numbers of signature fatty acids for defined organisms and to identify the organisms causing the shift in microbial community. Not only the complexity of the procedure but also the competition with DNA-based methods might explain why extraction procedure of Zelles (1999) has been used less often.

Joergensen and Emmerling (2006) presented a weighted mean of 5.8 for converting nmol PLFA into $\mu \mathrm{g}$ microbial biomass C. However, this conversion value did not gain much popularity, although a term "biomass" would require the conversion of measured cell components to microbial biomass C. One reason for this observed reluctance might be that the conversion of PLFA to biomass is biased by the fact that cultured microorganisms contain lower PLFA concentrations than starving soil microorganisms (Joergensen and Wichern 2008).

\section{Conclusions}

PLFA analysis will still be of interest over the next decades for estimating the contribution of the main microbial groups to the total soil microbial biomass, especially in combination with PLFA-specific $\delta^{13} \mathrm{C}$ analysis. PLFA give information on bacterial groups such as Gram-negative (cy17:0, 17:1 $\omega 8$,

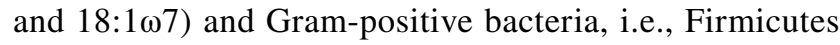
(i15:0, i17:0, and a15:0) and Actinobacteria (10Me17:0 and $10 \mathrm{Me} 18: 0)$ as well as fungal groups such as $\operatorname{AMF}(16: 1 \omega 5)$, Mucoromycotina (18:1 $\omega 9$ ), and Ascomycota + Basidiomy$\operatorname{cota}(18: 2 \omega 6,9)$. The straight-chain PLFA 14:0, 15:0, 16:0, and 17:0 occur in all microorganisms, i.e., also in fungi and not only in bacteria. PLFA analysis can be used as an important independent control of DNA-based methods. In this case, the comparison of membrane components and 16S-rRNA or 18S-rRNA gene abundance gives information on the cell size of bacteria and fungi under different growth conditions. The reliability and accuracy of gas chromatographic separation need to be regularly checked against unintentional variations. Important will be also to investigate more thoroughly the effects of soil properties, such as water content, on the extractability of PLFA to obtain the full potential of this approach.

Funding Open Access funding enabled and organized by Projekt DEAL.

\section{Declarations}

Conflict of interest The author declares no competing interests.

Open Access This article is licensed under a Creative Commons Attribution 4.0 International License, which permits use, sharing, adaptation, distribution and reproduction in any medium or format, as long as you give appropriate credit to the original author(s) and the source, 
provide a link to the Creative Commons licence, and indicate if changes were made. The images or other third party material in this article are included in the article's Creative Commons licence, unless indicated otherwise in a credit line to the material. If material is not included in the article's Creative Commons licence and your intended use is not permitted by statutory regulation or exceeds the permitted use, you will need to obtain permission directly from the copyright holder. To view a copy of this licence, visit http://creativecommons.org/licenses/by/4.0/.

\section{References}

Acosta-Martínez V, Dowd SE, Bell CW, Lascano R, Booker JD, Zobeck TM, Upchurch DR (2010) Microbial community composition as affected by dryland cropping systems and tillage in a semiarid sandy soil. Diversity 2:910-931

Allison VJ, Miller RM (2005) Soil grinding increases the relative abundance of eukaryotic phospholipid fatty acids. Soil Sci Soc Am J 69:423-426

Bååth E (2003) The use of neutral lipid fatty acids to indicate the physiological conditions of soil fungi. Microb Ecol 45:373-383

Bardgett RD, Hobbs PJ, Frostegård A (1996) Changes in soil fungal:bacterial biomass ratios following reductions in the intensity of management of an upland grassland. Biol Fertil Soils 22:261-264

Bligh EG, Dyer WJ (1959) A rapid method of lipid extraction and purification. Can J Biochem Physiol 35:911-917

Dippold MA, Kuzyakov Y (2016) Direct incorporation of fatty acids into microbial phospholipids in soils: position-specific labeling tells the story. Geochim Cosmochim Acta 174:211-221

Fanin N, Kardol P, Farrell M, Nilsson MC, Gundale MJ, Wardle DA (2019) The ratio of Gram-positive to Gram-negative bacterial PLFA markers as an indicator of carbon availability in organic soils. Soil Biol Biochem 128:111-114

Faust S, Heinze S, Ngosong C, Sradnick A, Oltmanns M, Raupp J, Geisseler D, Joergensen RG (2017) Effect of biodynamic soil amendments on microbial communities in comparison with inorganic fertilization. Appl Soil Ecol 114:82-89

Frostegård Å, Tunlid A, Bååth E (1991) Microbial biomass measured as total lipid phosphate in soils of different organic content. J Microbiol Meth 14:151-163

Frostegård A, Bååth E (1996) The use of phospholipid fatty acid analysis to estimate bacterial and fungal biomass in soil. Biol Fertil Soils 22:59-65

Frostegård Å, Tunlid A, Bååth E (2011) Use and misuse of PLFA measurements in soils. Soil Biol Biochem 43:1621-1625

Fu Z, Hu W, Beare MH, Müller K, Wallace D, Wai Chau H (2021) Contributions of soil organic carbon to soil water repellency persistence: characterization and modelling. Geoderma 401:115312

Guckert JB, Antworth CP, Nichols PD, White DC (1985) Phospholipid, ester-linked fatty acid profiles as reproducible assays for changes in prokaryotic community structure of estuarine sediments. FEMS Microbiol Ecol 31:147-158

Hamer U, Makeschin F, Stadler J, Klotz S (2008) Soil organic matter and microbial community structure in set-aside and intensively managed arable soils in NE-Saxony, Germany. Appl Soil Ecol 40:465-475

Hansen JC, Schillinger WF, Sullivan TS, Paulitz TC (2019) Soil microbial biomass and fungi reduced with canola introduced into longterm monoculture wheat rotations. Front Microbiol 10:1488

Jan U, Feiwen R, Masood J, Chun SC (2020) Characterization of soil microorganism from humus and indigenous microorganism amendments. Mycobiol 48:392-398

Jiang Y, Luan L, Hu K, Liu M, Chen Z, Geisen S, Chen X, Li H, Xu Q, Bonkowski M, Sun B (2020) Trophic interactions as determinants of the arbuscular mycorrhizal fungal community with cascading plant-promoting consequences. Microbiome 8:142

Joergensen RG (2018) Amino sugars as specific indices for fungal and bacterial residues in soil. Biol Fertil Soils 54:559-568

Joergensen RG, Emmerling C (2006) Methods for evaluating human impact on soil microorganisms based on their activity, biomass, and diversity in agricultural soils. J Plant Nutr Soil Sci 169:295-309

Joergensen RG, Wichern F (2008) Quantitative assessment of the fungal contribution to microbial tissue in soil. Soil Biol Biochem 40:2977-2991

Kaiser C, Frank A, Wild B, Koranda M, Richter A (2010) Negligible contribution from roots to soil-borne phospholipid fatty acid

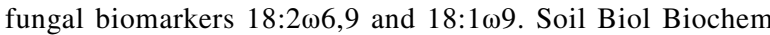
42:1650-1652

Kieft TL, Wilch E, O'Connor K, Ringelberg DB, White DC (1997) Survival and phospholipid fatty acid profiles of surface and subsurface bacteria in natural sediment microcosms. Appl Environ Microbiol 63:1531-1542

Lacombe-Harvey ME, Brzezinski R, Beaulieu C (2018) Chitinolytic functions in actinobacteria: ecology, enzymes, and evolution. Appl Microbiol Biotechnol 102:7219-7230

Li C, Cano A, Acosta-Martinez V, Veum KS, Moore-Kucera J (2020) A comparison between fatty acid methyl ester profiling methods (PLFA and EL-FAME) as soil health indicators. Soil Sci Soc Am J 84:1153-1169

Liang C, Kästner M, Joergensen RG (2020) Microbial necromass on the rise in SOM: the growing focus on its role in soil organic matter development. Soil Biol Biochem 150:108000

Lønne Enggrob K, Larsen T, Peixoto L, Rasmussen J (2020) Grampositive bacteria control the rapid anabolism of protein-sized soil organic nitrogen compounds questioning the present paradigm. Sci Rep 10:15840

Martínez-Abraín A (2008) Statistical significance and biological relevance: a call for a more cautious interpretation of results in ecology. Acta Oecol 34:9-11

Meyer S, Grüning MM, Beule L, Karlovsky P, Joergensen RG, Sundrum A (2021) Soil $\mathrm{N}_{2} \mathrm{O}$ flux and nitrification and denitrification gene responses to feed-induced differences in the composition of dairy cow faeces. Biol Fertil Soils 57:767-779

Miltner A, Bombach P, Schmidt-Brücken B, Kästner M (2012) SOM genesis: microbial biomass as a significant source. Biogeochem $11: 41-55$

Murugan R, Bhople P, Djukic I, Zehetner F, Keiblinger K, Zimmermann M, Zechmeister-Boltenstern S, Joergensen RG (2021) Temperature sensitivity of $\mathrm{CO}_{2}$ efflux in soils from two alpine elevation levels with distinct bedrock types. Appl Soil Ecol 162:103875

Nichols P, Stulp BK, Jones JG, White DC (1986) Comparison of fatty acid content and DNA homology of the filamentous gliding bacteria Vitreoscilla, Flexibacter, Filibacter. Arch Microbiol 146:1-6

Papadopoulou ES, Karpouzas DG, Menkissoglu-Spiroudi U (2011) Extraction parameters significantly influence the quantity and the profile of PLFAs extracted from soils. Microb Ecol 62:704-714

Veum KS, Lorenz T, Kremer RJ (2019) Phospholipid fatty acid profiles of soil under variable handling and storage conditions. Agron J 111:1090-1096

Wagner D, Gattinger A, Embacher A, Pfeiffer EM, Schloter M, Lipski A (2007) Methanogenic activity and biomass in Holocene permafrost deposits of the Lena Delta, Siberian Arctic and its implication for the global methane budget. Global Change Biol 13:1089-1099

Wang C, Lu X, Mori T, Mao Q, Zhou K, Zhou G, Nie Y, Mo J (2018) Responses of soil microbial community to continuous experimental nitrogen additions for 13 years in a nitrogen-rich tropical forest. Soil Biol Biochem 121:103-112 
Warren CR (2019) Does silica solid-phase extraction of soil lipids isolate a pure phospholipid fraction? Soil Biol Biochem 128:175-178

Willers C, Jansen van Rensburg PJ, Claassens S (2015) Phospholipid fatty acid profiling of microbial communities - a review of interpretations and recent applications. J Appl Microbiol 119:1207-1218

Wu Y, Ding N, Gang Wang G, Xu J, Wu J, Brookes PC (2009) Effects of different soil weights, storage times and extraction methods on soil phospholipid fatty acid analyses. Geoderma 150:171-178

Xu M, Cardenas LM, Horrocks C, López-Aizpún M, Zhang J, Zhang F, Dungait JAJ (2021) The effect of tillage management on microbial functions in a maize crop at different slope positions. Geoderma 401:115171

Yang S, Xu Z, Wang R, Zhang Y, Yao F, Zhang Y, Turco RF, Jiang Y, Zou H, Li H (2017) Variations in soil microbial community composition and enzymatic activities in response to increased $\mathrm{N}$ deposition and precipitation in Inner Mongolian grassland. Appl Soil Ecol 119:275-285
Zelles L (1997) Phospholipid fatty acid profiles in selected members of soil microbial communities. Chemosphere 35:275-294

Zelles L (1999) Fatty acid patterns of phospholipids and lipopolysaccharides in the characterisation of microbial communities in soil: a review. Biol Fertil Soils 29:111-129

Zhang Y, Zheng N, Wang J, Yao H, Qiu Q, Chapman SJ (2019) High turnover rate of free phospholipids in soil confirms the classic hypothesis of PLFA methodology. Soil Biol Biochem 135:323-330

Publisher's Note Springer Nature remains neutral with regard to jurisdictional claims in published maps and institutional affiliations. 